\title{
Facing the crisis: new challenges for competition policy Selected papers from the 2010 annual meeting of the Austrian economic association
}

\author{
Gerhard Clemenz $\cdot$ Maarten Janssen
}

Published online: 8 January 2011

(C) Springer Science+Business Media, LLC. 2011

The financial crisis that struck the world economy in 2008 affected not only the financial sector in many countries around the world, but also the real sector. One important aspect of the financial crisis was that it has lead to unprecedented levels of monetary and fiscal support, resulting in hundreds of billions of Dollars and Euros to rescue some of the biggest financial institutions of the world, and to support economic activity. This large size government intervention is surprising from the perspective of a quarter century of economic policy preceding the crisis, where deregulation was the main policy objective in most OECD-countries. Industries that had been considered natural monopolies in the past, thus requiring either direct or indirect government ownership and/or strict regulation, were privatized and deregulated. The underlying argument was that free and unfettered markets were best-equipped to ensure an efficient allocation of resources and to achieve sustainable economic growth and higher living standards for the vast majority of people. Privatization and deregulation were subsequently not confined to natural monopolies like telecommunication, railways, etc. but also changed the structure of the financial sector. In addition, in many countries including Austria, there was a substantial shift in the pension system from the government to private funds thereby feeding enormous amounts of money into the financial system.

Given the apparent tension between the policy objective of privatization and deregulation on one hand, and the size of government intervention over the last 2 years on the other hand, it was a natural decision, to deal at least with some aspects of the crisis at the Annual Meeting of the Austrian Economic Association in May 2010. In particular, we decided to focus on the consequences of the crisis for competition policy in Austria and in the EU. Before the financial crisis, competition policy could be seen to some extent to have replaced state ownership in Europe and regulation in the USA. After many years of policy geared towards privatization and

G. Clemenz $(\bowtie) \cdot$ M. Janssen

Department of Economics, University of Vienna, Hohenstaufengasse 9, 1010 Wien, Austria

e-mail: gerhard.clemenz@univie.ac.at 
deregulation the role of the state was confined to ensuring that no illegal cartels were formed and that no abuse of market power occurred. Often, the state went further and created an independent competition authority that was supposed to be in charge of this task. In addition, within the EU, some principles of competition policy were extended to state aid. In particular, state aid should not be seen to interfere with free competition and only be granted if no market solution were available.

As the Great Recession unfolded and its dimension was realized, governments took measures to fight it which departed substantially from the principles just outlined. The USA were the first to nationalize - though temporarily-endangered financial institutions and state aid was granted at an unprecedented scale. Moreover, mergers and takeovers-certainly in the financial sector-were also looked upon more favorably by the authorities than in less troubled times. Does this mean that competition policy, which had been reformed and intensified over the last decades in many EU countries, and not least in Austria, is useful at best in good times, just to be abandoned when the going gets rough? Separately, is there a role for competition policy in the prevention of severe crises? If so, what needs to be changed, what are the lessons to be learnt from the current crisis and what challenges lie ahead for economists?

The papers we have selected for publication in this issue tackle these and related questions.

In the first paper Lars-Hendrik Röller, former chief-economist of the DG Competition, discusses "Challenges in EU Competition Policy." While pointing out the positive developments in European Competition Policy, which he considers to be "one of the great achievements of European Integration" he identifies four areas in which further improvements are required: (1) the objective of EU-competition policy, (2) market definition, (3) state aid control, and (4) the balance between regulation and competition policy. He concludes that efficiencies should get a larger weight, supply side factors should play a larger role in market definition, and that a better coordination of competition policy measures with those in other policy areas is required.

In the second paper Michael Böheim refers explicitly to the great crisis and proposes "Ten Lessons Learnt From the Financial Crisis" for competition policy. One of his main conclusions is that "the relaxation of competition policy would be the wrong policy response" to a crisis, and he expresses skepticism with respect to the renaissance of industrial policy.

Kersten Kellermann discusses one of the main problems in dealing with the financial crisis, namely that some financial institutions are deemed to be "Too big to fail", with the consequence that they are being rescued even though this may well provide wrong incentives and prevent or at least delay necessary changes in financial markets.

While the three first papers discuss various issues of competition policy under the (implicit) assumption that competition, and thus all measures that intensify or at least maintain it, are beneficial, Klaus Weyerstrass and Johannes Jaenicke tackle the question whether "More competition is conducive to the macroeconomic performance in the euro area?" They take the mark-up as a proxy for the intensity of 
competition and show by means of panel estimations that "more competition could indeed improve the macroeconomic performance."

The following three papers deal with more theoretical aspects of competition policy and suggest ways to improve its efficiency. Nikolaus Fink considers "SSNIP, State-owned enterprises, public goods and complements," and points out that subsidies for a state owned monopolist may reduce consumer surplus if a complementary good is supplied competitively. He then discusses the possibility of applying competition law in such a setting.

Johannes Paha discusses the usefulness of "Empirical methods in the analysis of collusion". Using data generated by a simulation-model of a collusive industry he demonstrates "that thoroughly conducted econometric analyses yield better results than simple techniques such as before-and-after comparisons."

The third methodological paper by C. Steiner, K. Hüschelrath and J. Weigand analyses "Merger remedies involving restructuring costs in a Cournot framework". They point out that the implementation of divestiture remedies is costly and conclude that neglecting such costs implies excessive divestiture which leads to efficiency losses and a reduction of consumer surplus.

The Great Crisis has not only posed new challenges for competition policy but may also require rethinking of other economic policy areas. The last paper in this volume provides an example for this. R. Neck, D. Blueschke and K.Weyerstrass contribute a case study for Slovenia in order to shed some light on "Optimal macroeconomic policies in a financial and economic crisis." Using a simulation model of the Slovenian economy they "show that optimal policies call for an only very modestly active countercyclical role of fiscal policies," and they point out trade-offs between countercyclical fiscal policies and the requirements of fiscal solvency. 